\title{
14
}

\section{Policies for Later-Life Families in a Comparative European Perspective}

\author{
Pearl A. Dykstra and Maja Djundeva
}

Discussions of "family friendly" policies tend to focus on young children and their parents, as exemplified in Berger and Carlson's (2020) decade review of family policy in the Journal of Marriage and Family. The authors explicitly "retain the focus on families with children" despite acknowledging that "families come in a variety of forms that may or may not involve legal, biological, or intergenerational ties" (p. 479). The focus on young children and their parents is grounded in the principle that families produce and shape citizens of the future. Unfortunately, it disregards the fact that those parents are also children, even grandchildren, in a multigenerational family structure. Writing on public support to the oldest members of society comes under headings such as "pension policy", "health policy", or "longterm care policy" - as if people in later-life phases have no families. The neglect in family policy circles for persons who are helping older relatives is all the more remarkable given that growing numbers of frail older adults rather than growing numbers of children are putting pressure on families'

The original version of this chapter was revised: Table 14.1 has been updated with new corrections. The correction to this chapter is available at https://doi.org/10.1007/978-3-030-54618-2_27

\section{P. A. Dykstra $(\bowtie)$}

Erasmus University Rotterdam, Rotterdam, The Netherlands e-mail: dykstra@essb.eur.nl

M. Djundeva

Netherlands Institute for Social Research (SCP), The Hague, The Netherlands e-mail: m.djundeva@scp.nl 
ability to provide care (Kröger \& Yeandle, 2013). That families provide care to both young and old is acknowledged in the 2019 European Directive on work-life balance, ${ }^{1}$ which requires Member States to implement measures aimed at "allowing parents, and other family members with caring responsibilities to enter, remain in, or return to the labour market".

Across OECD countries, around $13 \%$ of people aged 50 provide care with everyday tasks to older family members, friends, and neighbors at least weekly (OECD, 2019a). Almost two-thirds of those providing daily care are women, especially spouses or adult daughters (in-law), but more men become carers at older ages. As improvements in survivorship continue, more people will find themselves living longer with multiple family generations (Murphy, Martikainen, \& Pennec, 2006). Whereas early studies on the "sandwich generation" focused on how women combined caring for frail parents and dependent children (Brody, 1981), later scholarship pointed out that the typical experience of "being caught in the middle" pertained to helping both aging parents and young grandchildren (Soldo, 1996). Furthermore, because of gender differences in age at marriage and life expectancy, women are more likely than men to simultaneously occupy the role of adult child and grandparent (Hagestad \& Dykstra, 2016). Research on those who are "sandwiched" between multiple generations, by having at least one parent/parent-in-law and one grandchild alive, goes against the assumption that helping the one generation comes at the expense of helping the other generation: more intense support for one generation is associated with a higher likelihood of supporting the other generation (Herlofson \& Brandt, 2019; Vlachantoni, Evandrou, Falkingham, \& Gomez-Leon, 2019). These findings support a "solidarity hypothesis" rather than a "competing demands hypothesis" (Grundy \& Henretta, 2006): those with strong commitments to solidarity tend to assist both generations rather than prioritize recipients, whereas those low in solidarity are less likely to help both generations.

In this chapter, we consider cross-national differences in policies for laterlife families in Europe, focusing on state support freeing family members from caring responsibilities or enabling them to care for older generations. These policies come under the umbrella of long-term care (LTC), help required by persons with a reduced degree of functional capacity (whether physical or cognitive) for an extended period of time (European Commission, 2018a). The policies are not only targeted at frail older adults but pertain to adults of all ages with a dependency on others. Publicly funded LTC includes "inkind" services, where care is provided by professionals at home or in an institution, and "cash benefits" which can be used to purchase professional

\footnotetext{
${ }^{1}$ https://eur-lex.europa.eu/legal-content/EN/TXT/PDF/?uri=CELEX:32019L1158\&from=EN.
} 
care or which can be paid to informal caregivers as income support. Apart from long-term care for dependents themselves, there are policies supporting family members in their caregiving tasks: "cash for care" (financial compensation for helping those with physical of cognitive impairments), "care leaves" (the right to be absent from work in order to care), and "care credits" (time spent on caring that is credited toward a basic pension). Note that the issue of financial responsibilities, providing money to older family members who have insufficient retirement income, is beyond the scope of this chapter.

\section{Models of Long-Term Care}

We start with a general overview of LTC models and adaptations to these models over the past 25 years. These adaptations have taken place in response to concerns about an expected decrease in the pool of family carers and a concomitant growth in demand for LTC, and in response to cultural shifts toward more self-determination for care users.

\section{General Overview}

In Europe, LTC provision is characterized by significant cross-national differences regarding the division of responsibilities between families, the state, for-profit organizations, and the volunteer sector. The differences in LTC models stem largely from cultural and political traditions regarding the role of families in society (Pavolini \& Ranci, 2013). Is care primarily a private obligation with the state stepping in only when absolutely necessary? Or, is care a social right, a basic need of citizens? Models of LTC define relations of generational interdependence (Dykstra \& Hagestad, 2016; Hagestad \& Dykstra, 2016): the extent to which public policy arrangements impose reliance on older and younger family members or enable individual autonomy between family generations (Frericks, Jensen, \& Pfau-Effinger, 2014; Leitner, 2003; Lohmann \& Zagel, 2016; Saraceno \& Keck, 2010).

Several LTC models have been identified, ranging from a residual model, also termed informal care-led model (Pavolini \& Ranci, 2008) or family care model (Anttonen \& Sipilä, 1996; Bettio \& Plantenga, 2004), to a universalistic model (Ranci \& Pavolini, 2015), also termed services-led model (Pavolini \& Ranci, 2008) or Scandinavian model (Anttonen \& Sipilä, 1996), with various intermediate models in between. In countries with a residual LTC model (most of the Mediterranean and central-eastern European countries), care for the frail is mainly provided by families, volunteer organizations, and religious associations. In countries with a universalist LTC model (the Nordic countries and the Netherlands), there is generous state funding for 
nursing care, personal care, and medical help via recognized institutions. Countries with an intermediate LTC model (Austria, France, Germany and the United Kingdom) have made significant financial investments into LTC in the past 25 years, at different times and following diverse institutional and organizational models (Carrera, Pavolini, Ranci, \& Sabbatini, 2013).

\section{Adaptations to Long-Term Care Models Over the Past 25 Years}

Recent decades have shown a blurring of differences in LTC models as countries have reacted to what scholars identified as "problem pressures" (Ferrera, 2005) and "new social risks" (Taylor-Gooby, 2004). One of the identified pressures concerns the supply of family care. International organizations like the OECD repeatedly report possible shortages of available kin to support older adults in the future (e.g. Haberkern, Schmid, Neuberger, \& Grignon, 2012). Due to reduced fertility rates and increased divorce rates there may be fewer adult children and spouses to take care of older adults in need. Note however, that having multiple children does not mean that all of them are providing care (Fontaine, Gramain, \& Wittwer, 2009). Moreover, increases in longevity imply that higher proportions of future older adults are likely to have a surviving child than any generation ever born (Murphy et al., 2006). If the family's capacity to provide support diminishes in the future, it is less likely the result of changes in fertility and mortality patterns, and more likely connected to changes in family structure (e.g. the increase of singleparent families), the unequal but steady rise in the labor force participation of women, and the changing nature of work which results in less free time, longer commuting, and greater residential distances between family members (Limmer \& Schneider, 2008). To support family carers, a limited number of countries have introduced cash benefits that are granted directly to the carer (e.g. Finland, Hungary, Ireland and the United Kingdom) and many countries have leave schemes that allow caring relatives to take some time off from gainful employment or to reduce their working hours (Spasova, Baeten, Coster, Ghailani, Peña-Casas, \& Vanhercke, 2018).

Numerous reports have pointed to financial pressures linked with the expansion of an older population in need of care. Notwithstanding a potential compression of morbidity, the numbers of older people with cancer, hip fractures, strokes, and dementia will grow, and many older people will have multi-morbidities (Rechel et al., 2013). Public spending on LTC is projected to increase from 1.6 to $2.9 \%$ of GDP in the EU between 2016 and 2070 (European Commission, 2018a). Although older people account for 
a substantial proportion of long-term care, other factors, especially progress in health sciences and the development and use of new technologies have a much larger effect on aggregate costs (De la Maisonneuve and Oliveira Martins, 2013). It has also been suggested that new generation of older people, who might be wealthier or more educated than were previous generations, will have greater demands for care services (Rechel et al., 2013). Cost containment measures that have been adopted in recent decades in countries with more generous care provisions include the freezing of service levels, shifts from institutional to home-based care, targeting care services to those with the most severe needs, and increased co-payments (Van den Broek, Dykstra, \& Van der Veen, 2019).

Changes in the organization of LTC provision can also be traced to cultural shifts emphasizing self-determination and autonomy with regards to care (Genet et al., 2011; Ranci \& Pavolini, 2013). The expansion of cash for care measures is at least partially a response to demands by disability groups for freedom of choice in care receipt (Da Roit \& Le Bihan, 2010, 2019; Le Bihan, Da Roit, \& Sopadzhiyan, 2019). Moreover, the growth of home-based care and the contraction of residential care in countries with universalistic LTC models fits older European's preferences to live in a familiar environment, traditionally the family home, as long as possible and to avoid moving to a form of institutional care (European Commission, 2007).

\section{Cross-National Comparisons of Long-Term Care Provisions}

In this section, we describe differences in LTC provisions across European countries, including changes over time. Cross-national comparisons are rather challenging, given differences in definitions of disability and dependency, divisions between government departments and state agencies in the delivery of care, and different methods of financing LTC (European Commission, 2018a). Differences in definitions provide additional complexity. Sometimes publicly funded LTC is used synonymously with "formal care", a broader category that also includes privately paid professional care. Sometimes "informal care" also includes care provided by family members that is partially paid by public funds in the form of cash for care benefits. Thus, merely distinguishing between formal and informal care does not capture the complex policy arrangements that vary greatly across European countries. Further challenges in the comparative investigation of LTC arise from country-specific definitions of long-term care services. 


\section{Availability of Beds}

Most countries provide information about beds in residential long-term facilities as a ratio between recipients and the older adult population (recipients per 1000 adults aged 65 and over). Unfortunately, definitions of what constitutes a "residential bed" have been subject to change. For example, in 2017, Austria reclassified large parts of alternative living facilities in residential long-term care facilities as inpatient services (OECD, 2019b). In 2012, the Netherlands expanded the definition of beds in residential long-term care facilities to also include places in care residences for disabled persons and not only nursing and residential care homes for older adults (OECD, 2019c).

Figure 14.1, based on harmonized data compiled by the OECD, reveals changes between 2005 and 2017 for 25 European countries in the availability of beds in residential long-term care facilities per 1000 persons of the population aged 65 and over. In a wide range of countries (Czech Republic, Finland, France, Iceland, the Netherlands, Norway, Poland, Sweden, Switzerland, United Kingdom), the number of beds decreased over time. Some of these reductions have occurred due to countries implementing policies to move LTC out of residential facilities and into the community (Colombo, LlenaNozal, Mercier, \& Tjadens, 2011). Deinstitutionalization is not a problem per se but becomes one when it is not matched with a sufficient and affordable increase in home care and community-care provision (Spasova et al., 2018). Germany, Italy, Lithuania, and Slovakia, and more so Estonia and Spain show modest increases in the availability of residential long-term care.

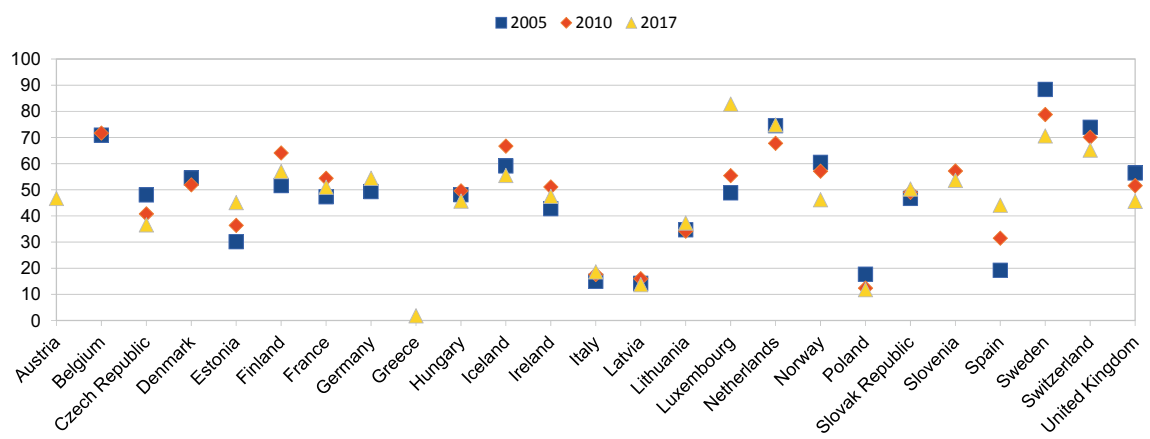

Fig. 14.1 Beds in residential long-term care per thousand of the total population aged 65 and over, selected European countries, 2005-2107 


\section{Long-Term Care at Home}

The OECD also has harmonized data on developments between 2005 and 2017 in the receipt of long-term care at home (see Fig. 14.2). Data for some countries refer only to people receiving publicly funded care, while other countries include people who are paying for their own care (OECD, 2017). In 2017, the proportion of over-65s receiving long-term care at home varied from $1 \%$ in Portugal to $16 \%$ in Switzerland. The proportion of LTC recipients living at home declined over the past decade in Denmark, Finland, the Netherlands, and Norway-countries with a universalistic LTC model. The decrease of home-based care in these countries is linked to fiscal measures aimed at cost containment and greater means-testing of services (Spasova et al., 2018). The decrease in Estonia is attributable to a reduction of the number of "curators" appointed by local government to care for people at home (OECD, 2017). An expansion of home-based care is evident in Italy, Portugal, and Spain-countries where home care services were relatively underdeveloped. In Germany, Hungary and Sweden, the expansion resulted from a deliberate policy to strengthen community care (Spasova et al., 2018). The proportion of older adults receiving long-term care at home also increased in Switzerland, a country where LTC costs are predominantly funded from private sources (Colombo et al., 2011). The proportion of LTC recipients living at home showed no change in France, Luxembourg, and Slovenia, which belong to the group of countries where home care has priority over residential care (Spasova et al., 2018).

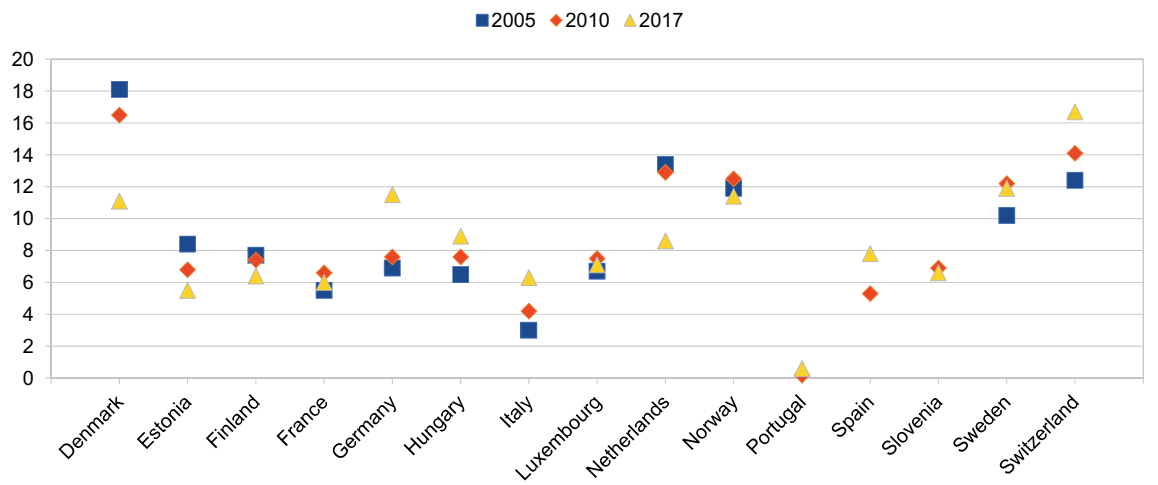

Fig. 14.2 Recipients of long-term care at home as percentage of the total population aged 65 and over, selected European countries, 2005-2107 


\section{Cash for Care}

A novelty since the 1990s in long-term care schemes in Europe has been the introduction of cash for care policies (see the left-hand column of Table 14.1 for an overview), but it served different purposes and was elaborated in different ways (Da Roit \& Le Bihan, 2019). In some countries (e.g. the United Kingdom), cash benefits were primarily framed as compensation for the costs of disability. In other countries (e.g. the Netherlands), the rationale for introducing cash benefits was to increase users' choice and control, in addition to cost containment. In yet other countries (e.g. Germany), the cash benefit was designed as support for family caregivers. Finally, there is the model of fee for professional service along with creating and regularizing care employment (e.g. Spain). Not surprisingly, given the different rationales underlying their introduction, cash for care schemes differ widely across Europe (Spasova et al., 2018). One difference pertains to eligibility: it can depend on the degree of care dependency, income and assets, and the age of the dependent person. Countries also differ widely regarding the requirements on the use of and accountability for the cash benefit. At one end of the spectrum, the benefit serves as an income supplement for the household without any requirements on how it is spent. At the other end, the benefit is to be used only to pay for professional services and home assistants. Some countries require proof of a formal employment contract. There is also considerable variation in payment levels, which is a function of the roles cash benefits play in each country's LTC program (Nadash, Doty, Mahoney, \& Von Schwanenflugel, 2010). As noted earlier, a limited number of countries grant cash benefits directly to the carer (Spasova et al., 2018). Such a program can act to replace lost income, linked to social protection coverage, but can also serve as recognition (albeit often symbolic) of the labor of caring.

\section{Care Leaves}

Leave policies focus on the well-being, labor force attachment, and work-life balance of the carer rather than the person being cared for. All European Union countries, with the exception of Cyprus and Latvia have introduced leave schemes in recent decades (see the middle column of Table 14.1 for details). The leaves are not necessarily only for workers caring for frail older adults but also for workers caring for ill and handicapped adults more broadly. Most countries have both short- and long-term leaves, and they generally allow the carer to continue building up social security rights (Bouget, Spasova, \& Vanhercke, 2016). Moreover, job protection is guaranteed during 


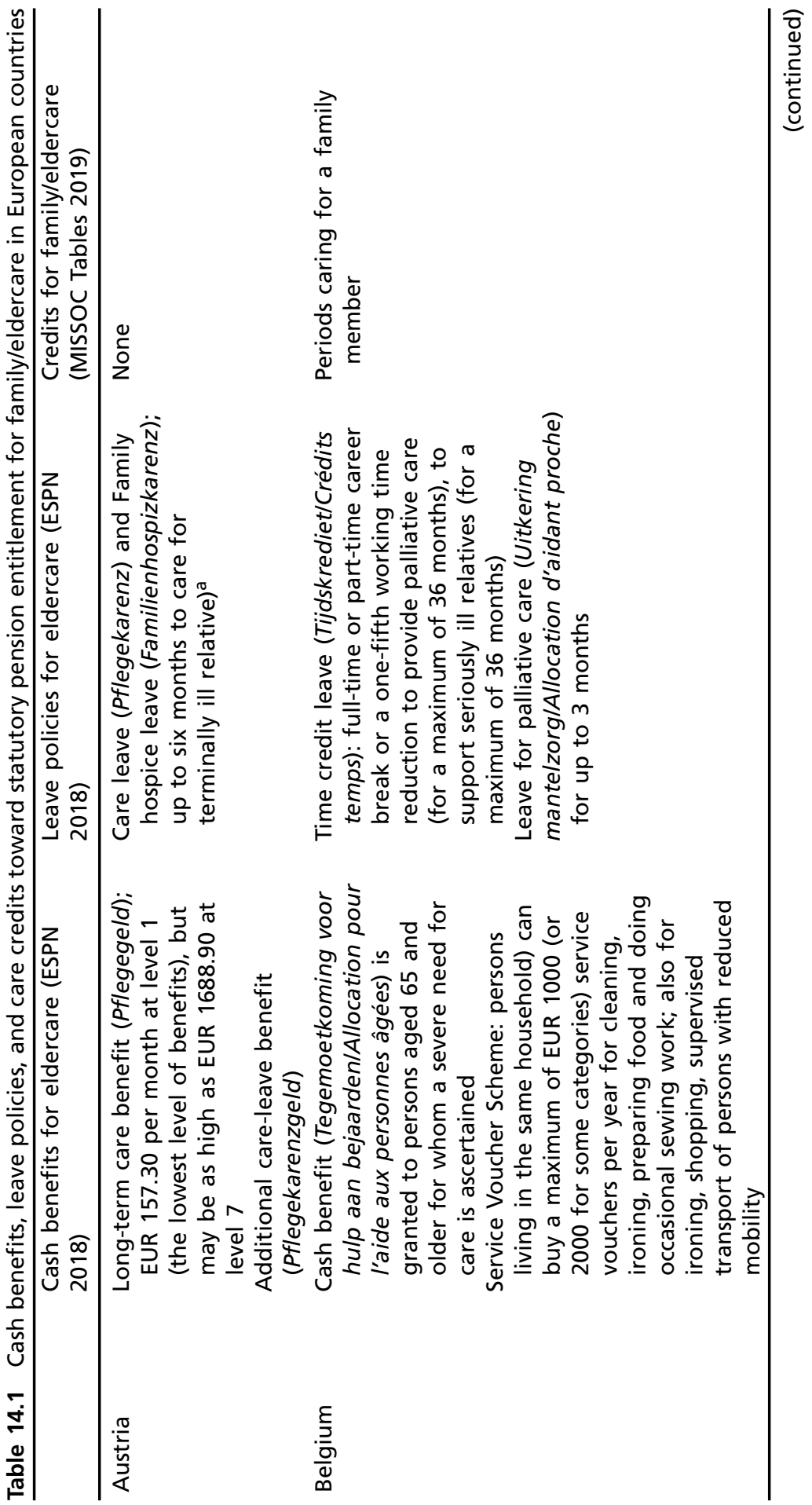




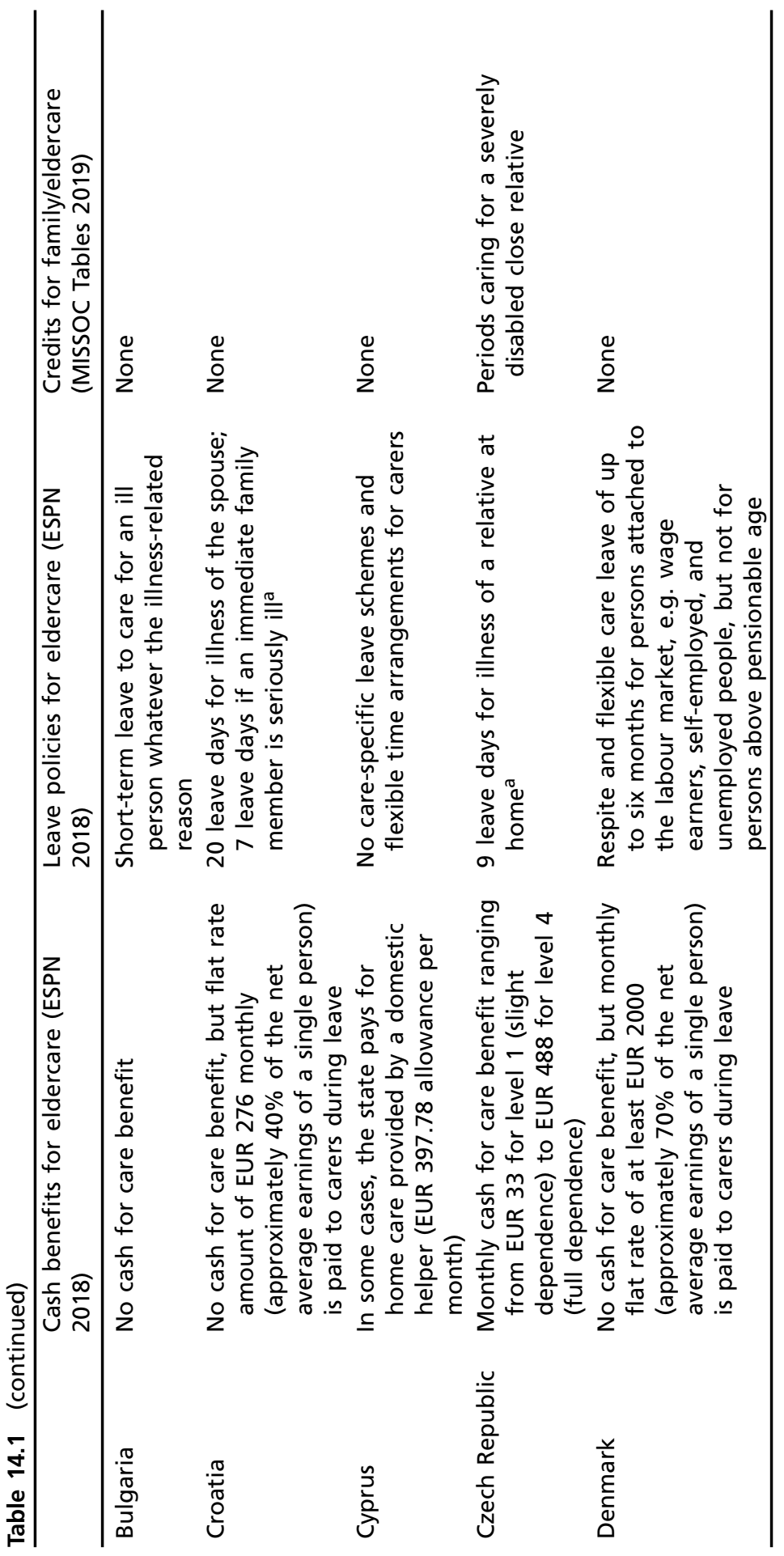




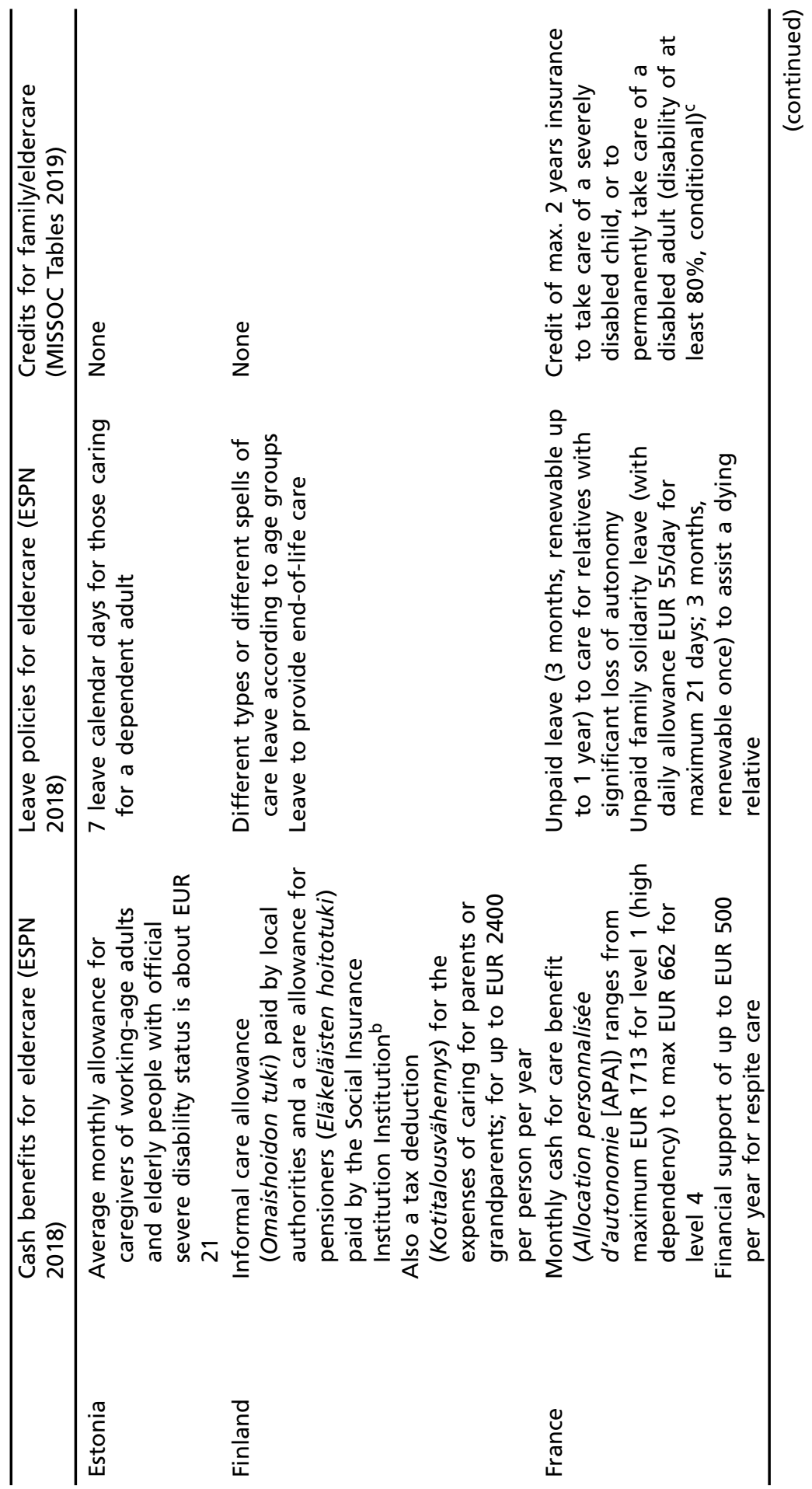




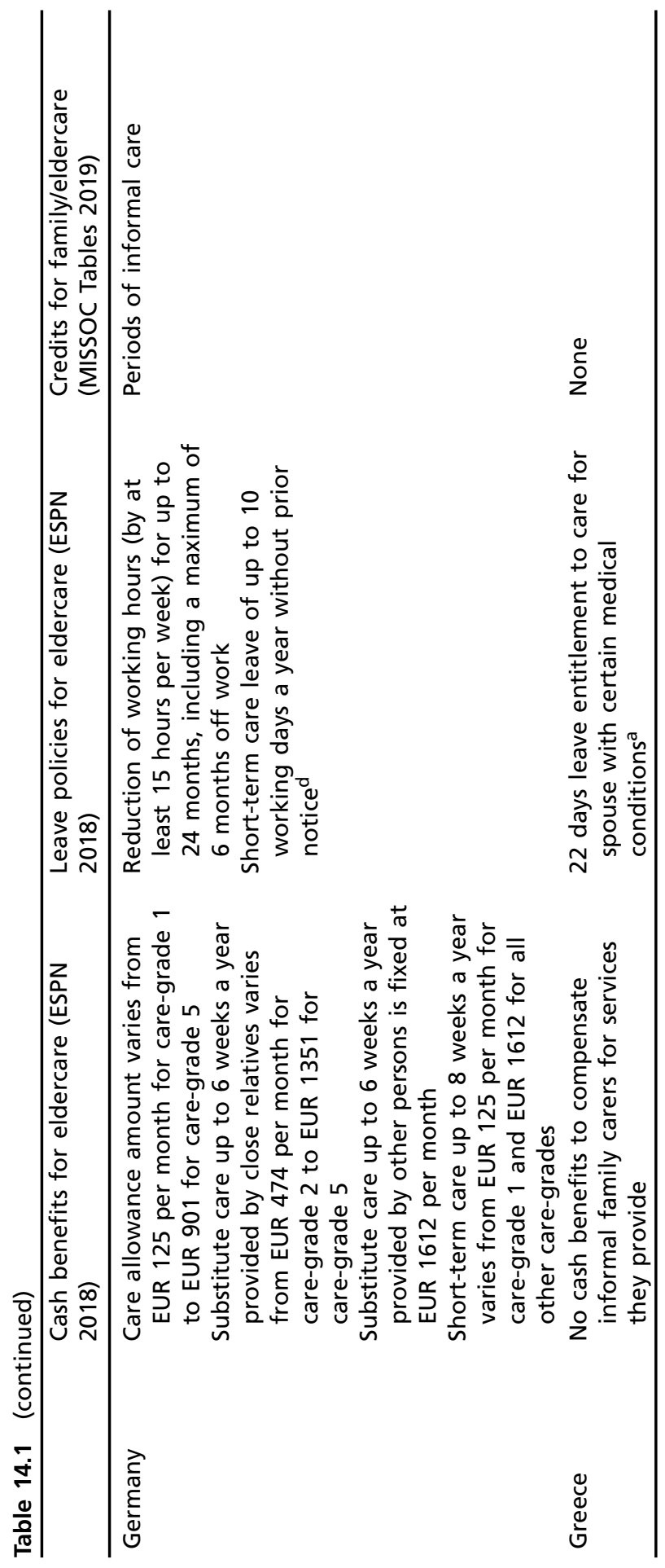




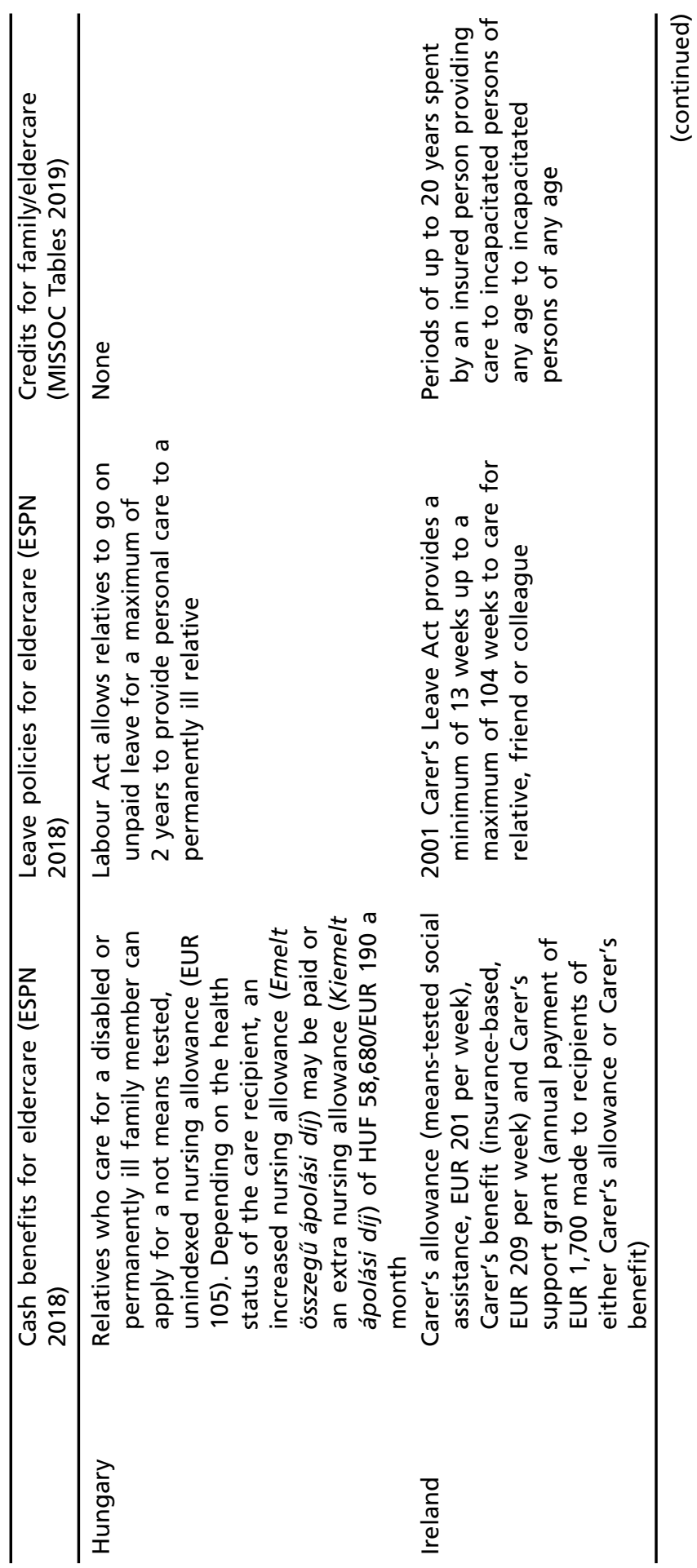




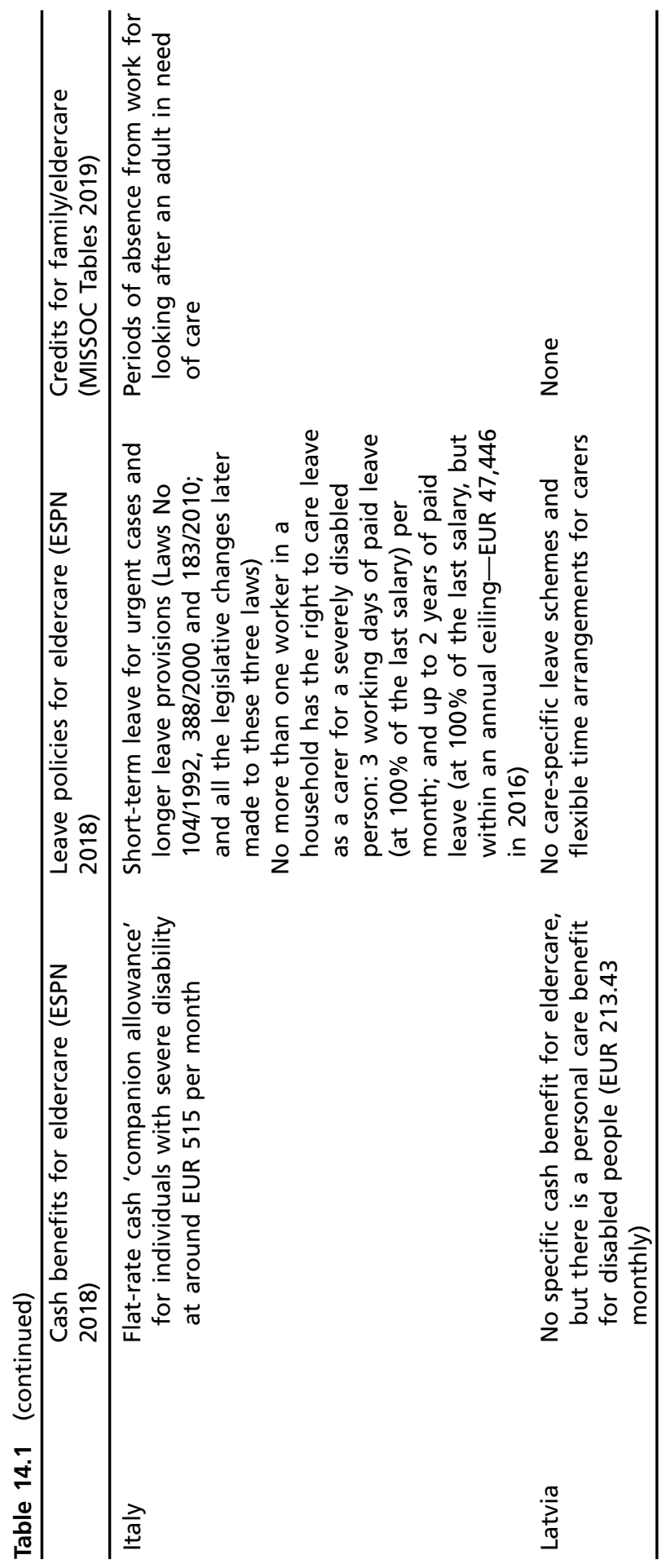




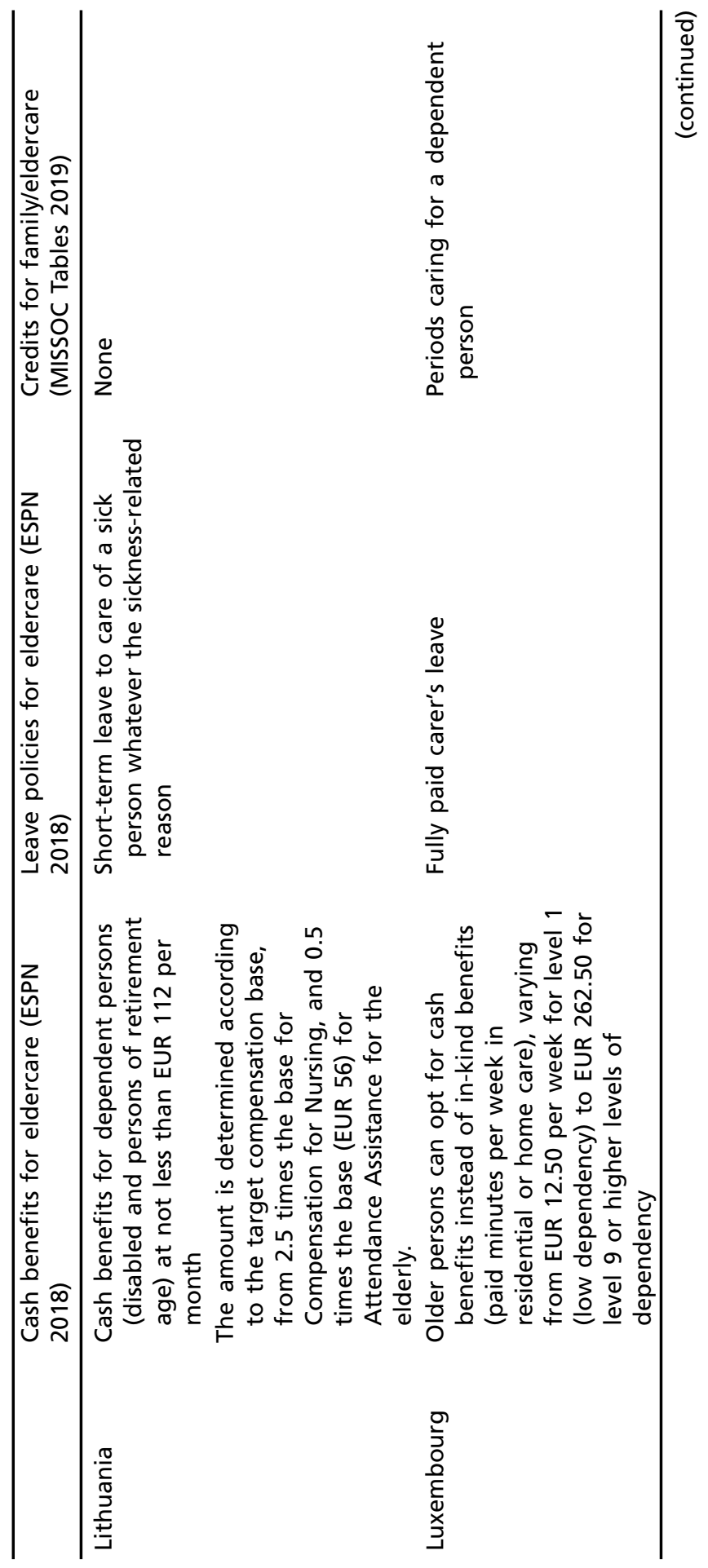




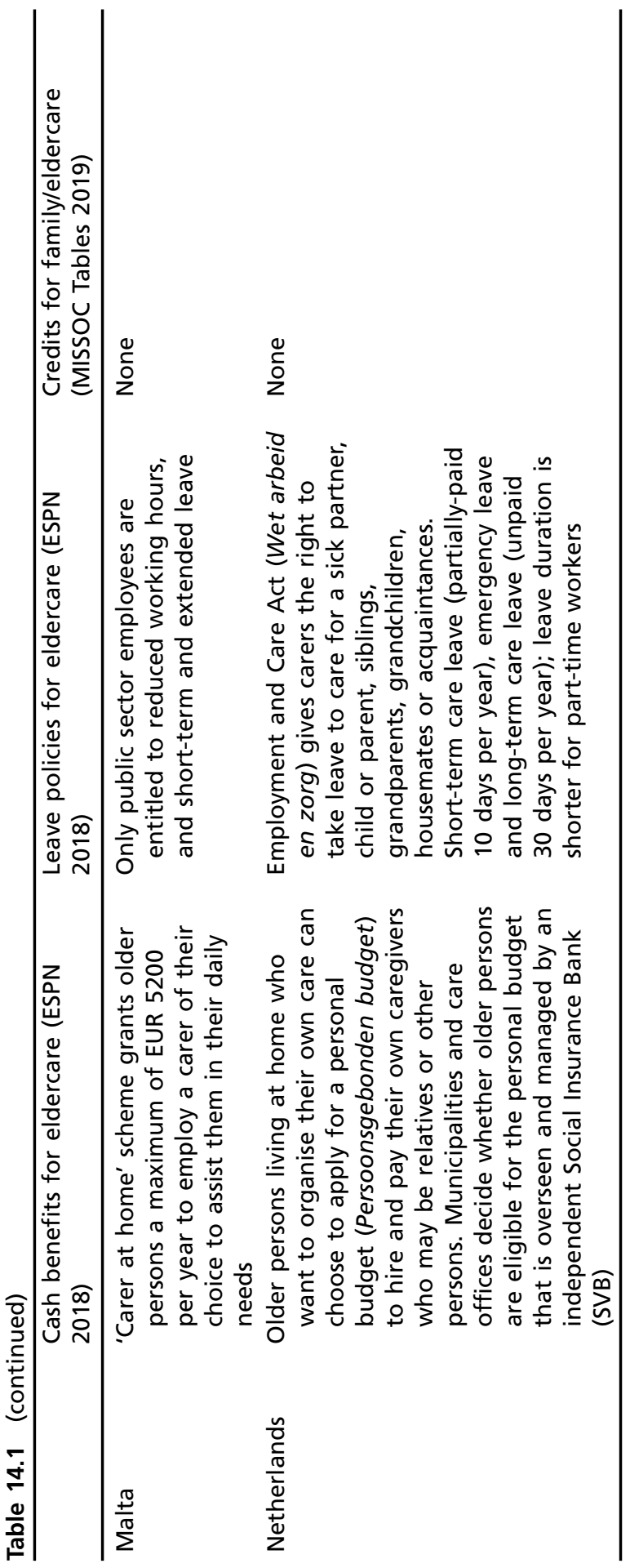




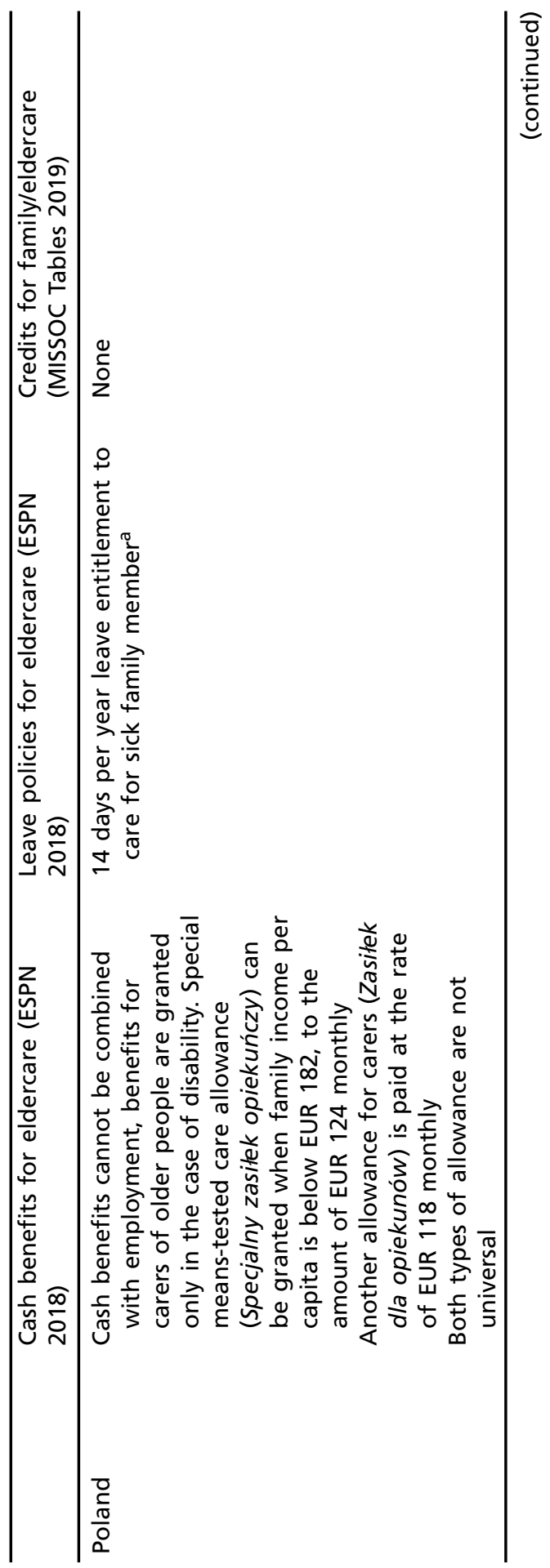




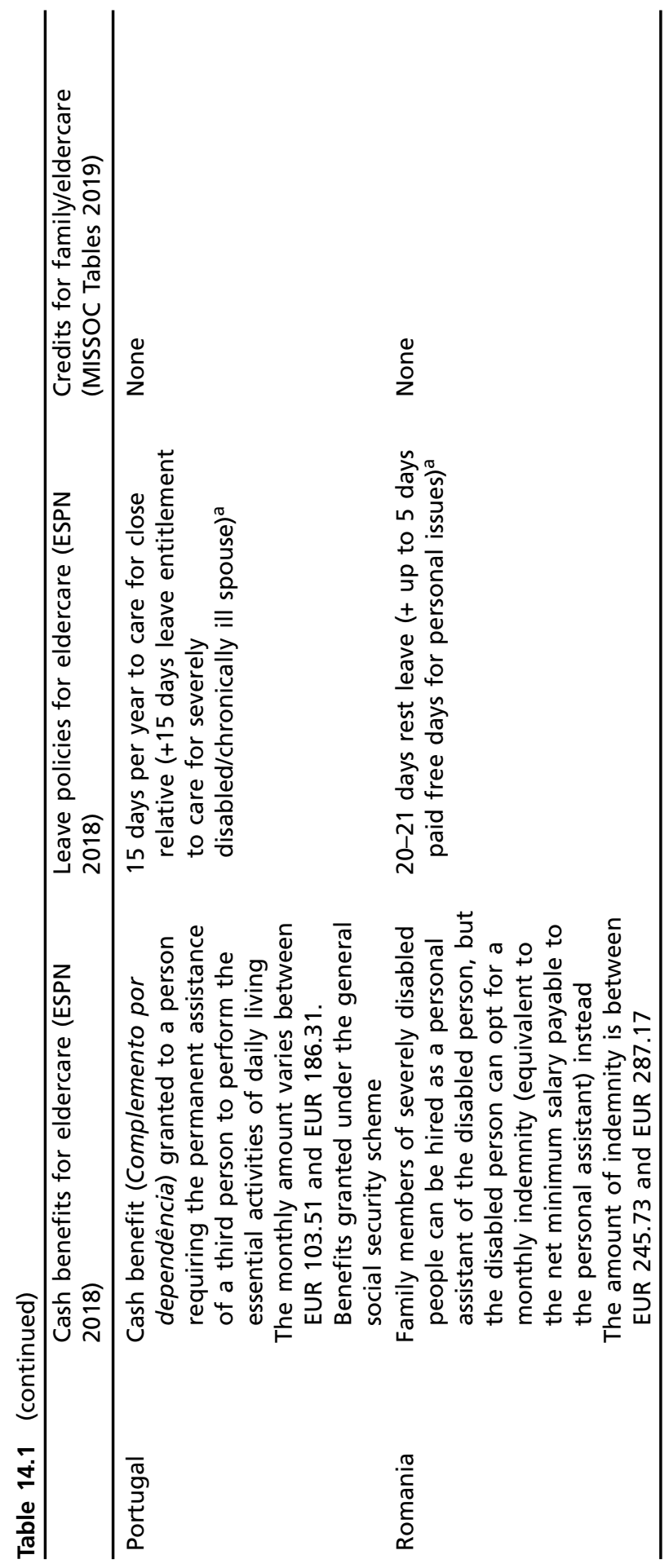




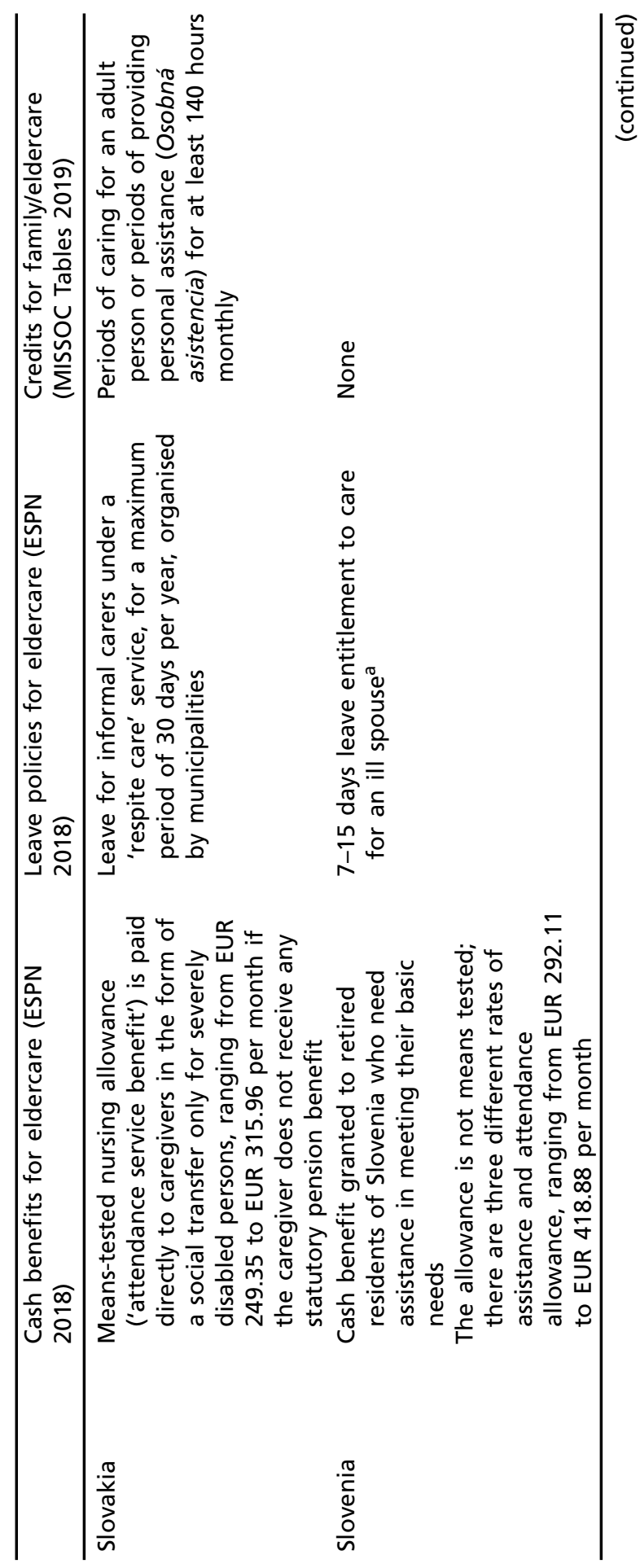




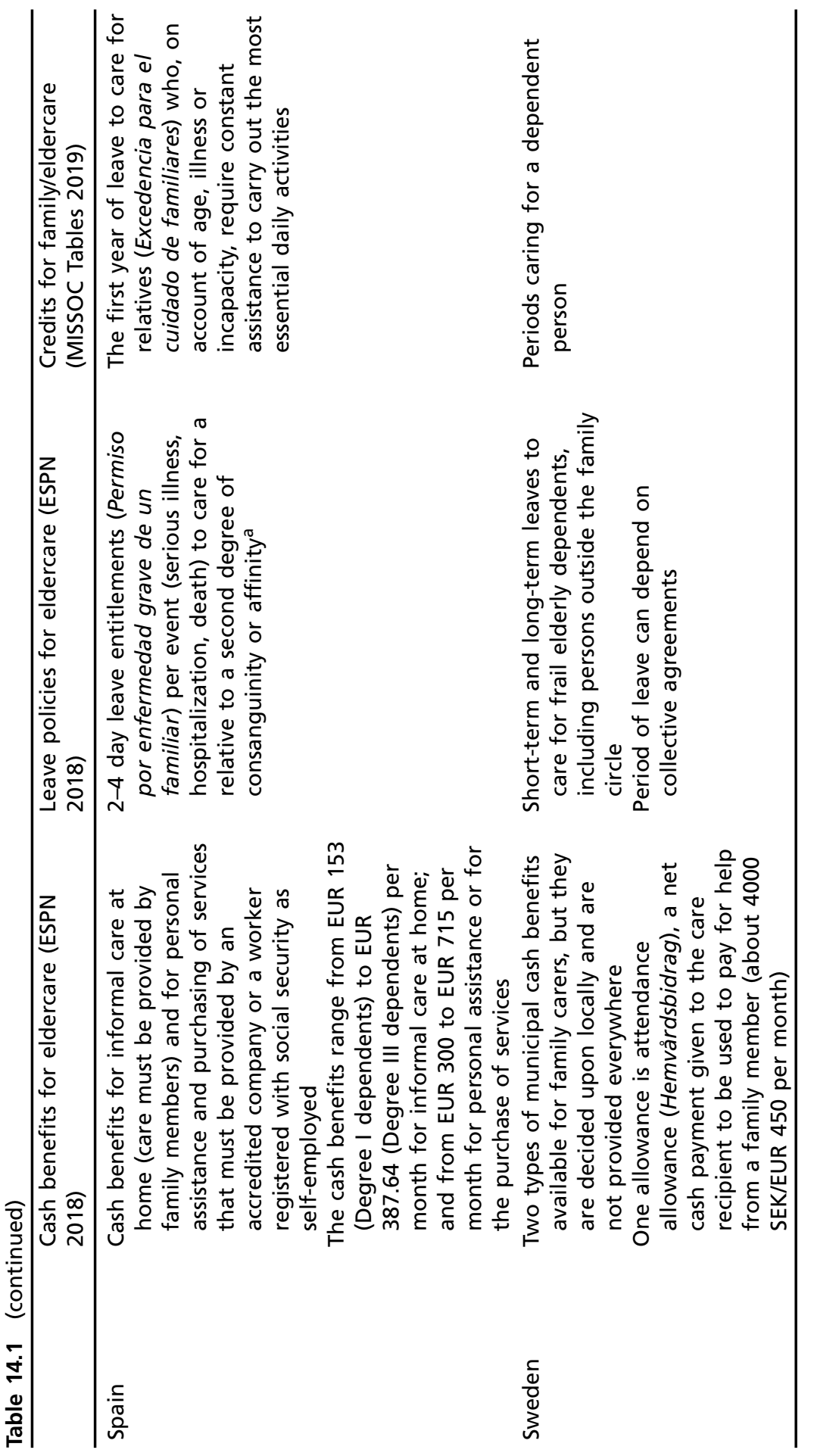




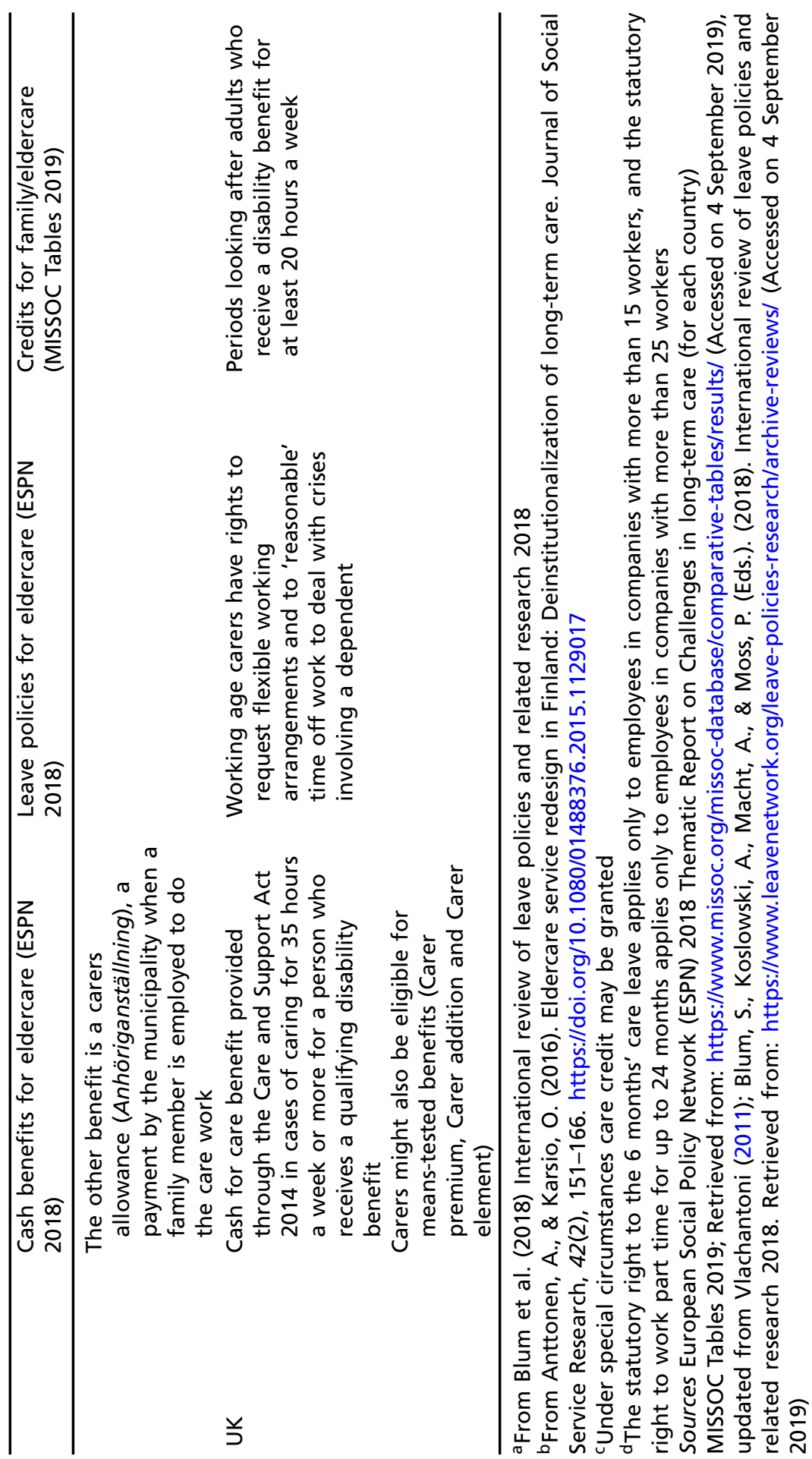


the carer's leave. Remuneration also varies: some countries apply a flat rate (e.g. Belgium, Denmark and Hungary), others pay a proportion of previous earnings subject to various ceiling conditions. In Denmark, Ireland, the Netherlands, Norway, Sweden, and the United Kingdom, workers are entitled to leave to look after dependents outside the family circle (Bouget et al., 2016). Unfortunately, information on the take-up or non-take-up of care leaves is often unavailable (Heymann, McNeill, \& Earle, 2013). Hence, it is unclear to what extent factors such as non-payment, lack of flexibility or perceived barriers restrain workers from using the leaves to which they are legally entitled.

\section{Care Credits}

In late life, the risk of poverty is generally higher for women than for men (European Commission, 2018b). Reasons are women's over-representation in less paid occupations, a lower statutory pension age for women in a number of countries, and women's greater likelihood to engage in part-time work or to have career breaks due to caring activities (D’Addio, 2013). To mitigate pension inequalities, a number of countries provide care credits that count toward a basic state pension, but such credits are more often given as compensation for childcare rather than care for handicapped adults or eldercare (Vlachantoni, 2011). Care credits reflect an amount of time in months/years that is "credited" to the carer's working record as if the carer were employed in the labor market. They do not, however, compensate for wage penalties associated with being outside the labor market (D'Addio, 2013). Care credits are also available to men, but the large majority of recipients are women (European Commission, 2018b). The right-hand column of Table 14.1 shows that fewer than half of EU-28 countries offer pension credits for periods providing unpaid care to adult dependents. It is important to note that that countries like Denmark, Finland, and the Netherlands do not offer credits for family or eldercare because their basic old-age pension is based on years of residence, and hence automatically covers periods spent outside the labor force providing unpaid care (D'Addio, 2013). Care credits are a topic of debate in the policy literature (Foster, Chau, \& Yu, 2017). The issue concerns the extent to which they promote women's emancipation or perpetuate existing structures of gender inequality (Ray, Gornick \& Schmitt, 2010). One view (espoused by "care feminists") is that care credits are a justified reward for invaluable unpaid activities that generally fall on women. An opposing view (espoused by "employment feminists") is that care credits create disincentives 
to engage in gainful employment and reinforce traditional assumptions about gender roles.

\section{Long-Term Care Policies and Caregiving in Families}

The last part of this chapter focuses on the ways in which LTC arrangements shape caregiving in European families. We describe the division of responsibilities between families and the state, and how this division changes in response to policy changes. We also consider to what extent public arrangements lighten the task of providing care to frail relatives, acknowledging that providing care to an aging family member may lead to costs, for instance, related to lost working days and foregone career opportunities, and to health problems (European Commission, 2018a). We end with a specific focus on unfavorable consequences of cash for care policies. Throughout we consider ways in which the policy context shapes inequality with respect to both class and gender, not only among frail older adults but also among those who care for them.

\section{Specialization Between Families and the State}

Early research on the intersection of families and the welfare state was guided by policy concerns that public provisions would weaken family members' propensity to care for their dependents. By now, cross-sectional findings have repeatedly shown that generous long-term care services complement rather than "crowd out" family care (Motel-Klingebiel, Tesch-Roemer, \& Von Kondratowitz, 2005). The availability of social service professionals in a given country shapes the types of supportive tasks that adult children perform for their aging parents (Dykstra, 2018). It is crucial to distinguish practical help (e.g., assistance with household tasks, paperwork) and physical care (e.g., assistance with bathing, dressing, eating) given to parents. The proportion of adult children providing practical help to parents is higher, but the proportion providing physical care is lower in countries with a larger social service sector (e.g. Attias-Donfut, Ogg, \& Wolff, 2005; Bonsang, 2007; Brandt, Haberkern, \& Szydlik, 2009). There is a "crowding in" of practical help, but a "crowding out" of physical care. When professionals take on the complex, demanding, and routinizable physical care tasks, family members have greater opportunities to provide spontaneous and non-technical forms of 
help. Hence, professionals and family members specialize in performing caregiving tasks for which they are best equipped (Balia \& Brau, 2014; Brandt, 2013; Igel, Brandt, Haberkern, \& Szydlik, 2009).

\section{Family Caregiving in Response to Changes in Long-Term Care Provision}

The expansion of repeated cross-sectional data sets has enabled research into the impact of changes in LTC provision on exchanges in families. Pickard's (2012) study is rather unique because it considers both the expansion and subsequent retrenchment of institutional care in the United Kingdom. She shows that the increase in residential long-term stay for older people during the late 1980s and early 1990s led to a decline in the most intense types of intergenerational care, but when numbers in nursing homes/hospitals began to fall in the late 1990s, very intense co-resident care by adult children began to rise. The majority of studies have solely focused on the effects of decreases in access to publicly funded long-term care services. In the United Kingdom (Patsios, 2008) and Sweden (Johansson, Sundström, \& Hassing, 2003) cutbacks in the 1980s and 1990s in care provided to older adults in the community were accompanied by increases in the provision of care by relatives and in the purchase of private help. Apparently, when the coverage of public services declined, older people turned to their families and to the market. A similar pattern has been observed in Finland, where declining eldercare services since the 1990s have been followed by an increase in family care (Kröger \& Leinonen, 2012) and a marketization of social care (Anttonen \& Häikiö, 2011). In the Netherlands, stricter eligibility criteria for LTC services introduced in the 2000s have also been accompanied by a rise in care provided by adult children (Van den Broek et al., 2019). We have not found any studies from Southern, Central and Eastern Europe on family care over time.

A number of investigations have revealed that the decrease in public provisions in Sweden affected older people in different social groups in different ways: those with more economic resources increasingly bought services on the market, whereas older people with fewer economic resources increasingly received help from family members (Jegermalm \& Grassman, 2012; Szebehely \& Trydegård, 2012). Another issue has been whether cutbacks in public provisions have differentially affected the help-giving roles of adult sons and daughters (Van den Broek, 2013). Findings are mixed. Focusing on the period 1994-2000 in Sweden, Johansson et al. (2003) found an increase in help by adult daughters but not by adult sons. Ulmanen and Szebehely (2015), 
whose study covers the period 2002-2010 in Sweden, found an increase in help by adult daughters mainly among older adults with lower education and an increase in help by adult sons mainly among older adults with higher education. Thus, the assistance given by children became more gender equal among older people fewer resources, and less gender equal among those with more resources. In the Netherlands, daughters more often provided household support to parents than did sons between 2002 and 2014, but there was no increase in the gender gap over time (Van den Broek et al., 2019).

\section{Policies Mitigating the Risks of Caregiving}

The act of giving is rewarding in the sense of being valued by and being important to others (Batson, 1998). Nevertheless, the provision of unpaid care to dependent family members or friends can be costly-to one's health and to one's financial status. A wide body of research has demonstrated a negative relationship between informal caregiving and well-being outcomes such as depression, stress, self-efficacy, general subjective well-being, and physical health (Pinquart \& Sørensen, 2003). Assessing the causal impact of caregiving on mental and physical health in a recent review of studies, Bom, Bakx, Schut, and Van Doorslaer (2019) reported that especially female and married caregivers and those providing intensive care experience negative health effects Bom et al. (2019). Studies investigating whether the magnitude of costs to well-being depends on the policy context are starting to emerge. Verbakel (2014) shows that the negative relationship between caregiving and happiness was smaller in European countries that provide more generous public LTC resources, and greater in those with few LTC provisions. Interestingly, the gap in happiness between caregivers and non-caregivers did not vary by level of services offered to informal caregivers, such as leaves, cash benefits, flexible work hours, counseling, and respite care. Rather crude measures of support services might be the reason why no effect was found. Verbakel suggests that future work should measure services more precisely, and determine which types help, under which conditions, for which groups of caregivers. Using data collected between 2004 and 2015, Van den Broek and Grundy (2018) examined the influence of declines in LTC coverage on caregiver quality of life in Denmark and Sweden. Both countries traditionally had generous LTC coverage, but cutbacks were implemented in the 1990s in Sweden and after 2005 in Denmark. Over time, the difference between Denmark and Sweden in the magnitude of the negative impact of caregiving on quality of life lessened. Presumably, caregiving was more strongly 
perceived as a matter of choice in Denmark at the start of the period under examination, and less strongly so at the end.

A large part of the financial costs of caring for frail family members, a role that is more often adopted by women than men (Eurofound, 2016), derive from temporary or permanent detachment from the labor force. Women's greater responsibilities for caregiving influence their labor supply decisions in ways that reduce earnings and make them less attractive to employers (Folbre, 2018). Care credits partially help to compensate the loss of pension benefits as the result of interruptions of the employment career to provide care to family members (European Commission, 2018b). Most research has focused on how LTC policy arrangements might influence the labor force participation of family carers. Consistent with the hypothesis that women are more likely to give up work if there is no viable alternative to family care, Kotsadam (2011) found that the effects of caregiving on women's labor force participation were more negative in Southern Europe (Portugal, Spain, Greece, Italy), less negative in Nordic countries (Denmark, Finland), and in between these extremes in Continental Europe (Netherlands, Germany, Belgium, France). Contrary to Kotsadam, who did not include actual measures of policies in his analysis, Naldini, Pavolini, and Solera (2016) incorporated indicators of home care and residential facilities in addition to total public spending on LTC in their comparison of women's labor force participation in 21 European countries. Their findings show that women's attachment to the labor force was stronger in countries with generous state support in the form of home care or residential homes. Total expenditure on LTC did not make a difference, suggesting according to the authors, that the type of policy rather than the total effort is a crucial determinant of carers' employment career. Services such as home help and institutional facilities enable carers to be gainfully employed, whereas cash for care schemes encourage carers, particularly those with lower levels of education, to give up work by providing an alternative source of income (Frericks et al., 2014; Leitner, 2003; Saraceno, 2010).

\section{Unfavorable Consequences of Cash for Care Schemes}

Studies on the impact of the type of LTC policy on caregiving in families are starting to emerge, with a specific focus on unfavorable consequences of cash for care schemes. One of them is increased gender inequality in intergenerational care (Da Roit, Hoogenboom, \& Weicht, 2015; Pavolini \& Ranci, 2008). Intended to enable choice in care receipt and to support the activities of informal carers, evidence suggests that cash for care benefits subtly incentivize women to fall back on traditional divisions of roles. Using data 
from 14 European countries, and confirming earlier findings, Haberkern, Schmid, and Szydlik (2015) show that women were more likely to provide intensive care to aging parents than men are. However, the gender gap in the provision of such care was highest in countries with low provision of professional home care services and high public spending on cash benefits. Additional analyses revealed that professional home care services substituted only for care by daughters, not for care by sons, who showed lower levels of engagement generally. Moreover, cash payments encouraged intergenerational care, but motivated only daughters not sons. Apparently, public services (home help and home nursing) reduced inequality in intergenerational care by reducing the engagement of daughters, whereas cash for care payments increased inequality in intergenerational care by increasing the engagement of daughters. In general, caregiving by sons was hardly influenced by social care policies. Another unfavorable consequence of cash for care schemes, particularly when users can freely spend their benefits, is unregulated marketization of care (Lutz \& Palenga-Möllenbeck, 2010; Saraceno \& Keck, 2010). In Italy, for example, families have increasingly resorted to often undocumented low-paid migrant workers providing around the clock care (Da Roit $\&$ Weicht, 2013), a development that is facilitated by a considerable level of undocumented migration and a large underground economy.

\section{Conclusion}

The 2017 European Pillar of Social Rights ${ }^{2}$ lists access to "affordable longterm care services of good quality, in particular home care and communitybased services" as one of its twenty core principles. To what extent do European countries guarantee their aging citizens this right to long-term care? Our overview of developments since the 1990s in LTC systems across Europe revealed "limited convergence" (Ranci \& Pavolini, 2013, p. 312): while universalistic systems retrenched their provisions, most of the residual care regimes expanded theirs. The exception is Italy, which undertook no major reform in its LTC policies and by default uses cash for care schemes (Costa, 2013; Da Roit \& Le Bihan, 2019). Our review has also revealed that, notwithstanding the "limited convergence", several countries in Europe, particularly in Southern and Eastern regions, do not ensure that their aging citizens have access to timely and affordable long-term care of appropriate quality. In

\footnotetext{
${ }^{2}$ https://ec.europa.eu/commission/priorities/deeper-and-fairer-economic-and-monetary-union/eur opean-pillar-social-rights_en.
} 
these countries, the more affluent can purchase care services at market price, whereas poorer people have few other options than to turn to their families.

Across Europe, the broad changes in long-term care provision have involved shifts toward more home care, more cash for care, less residential care, and greater targeting to those with the most severe needs (Ranci \& Pavolini, 2015). In countries with universalistic systems, the driving forces were not only cost containment but also served the purpose of meeting demands for free choice and consumer direction. In countries with residual care regimes, the reforms offered new entitlements but were also aimed at supporting the caring role of families. Throughout Europe, there has been a trend toward refamilialization of care, that is, shifting responsibility for long-term care from the state to individuals and their families (Ranci \& Pavolini, 2013). Both "passive" (i.e. withdrawal by the state) and "active" (i.e. introduction of cash for care benefits) re-familialization have occurred (Leibetseder, Anttonen, Øverbye, Pace, \& Vabo, 2017). In addition, there has been a trend toward marketization of care, where those in need of long-term care receive publicly funded services from private providers or pay for services out-of-pocket, with some financial compensation through tax rebates (Ranci \& Pavolini, 2013). Our review has revealed that re-familialization and marketization bring the risk of a dualization of care (Szebehely \& Meagher, 2018), where high-resource older adults find the best providers and low-resource older adults are faced with declining public service coverage.

As noted by Colombo and colleagues (2011), cash benefits should not be regarded as the sole policy option to support family carers. There is a trade-off between financial incentives for family caring and possible inappropriate use of cash benefits or the emergence of unregulated gray labor markets. There is also the risk of trapping family carers (predominantly women) into low-paid roles with few incentives for participating in the labor market. Services to support family carers are also needed, such as the provision of information, basic training, work reconciliation measures, and flexible respite options.

The shift toward more home care and less residential care fits efforts to enable older people to "age in place" (Lawton, 1982): to live independently in their own homes for as long as possible. There is a crucial distinction, however, between "ageing in place" and simply "staying put" (Boldy, Grenade, Lewin, Karol, \& Burton, 2011). Services must be available to enable older people to live in their own "place". Moreover, for those facing poor housing conditions, the home is not an appropriate environment to "age in place". Coping at home for too long can result in great harm, leading to physical and mental exhaustion for both the older people and their carers (Horner \& Boldy, 2008). Coordination between multiple care providers is necessary to avoid that older adults living in the community fail to be noticed or assisted. 
Research on the ways in which state support frees family members from caring responsibilities or enables them to care for older generations has made great strides. Nevertheless, while covering the literature, we have identified areas requiring further study. The first is how family policies might reduce the gendered division of caregiving. The strong focus on women in research on the intersecting spheres of work and family overlooks the question of what combination of care-friendly policy could, even over a long-term, decrease gender inequality. Research is needed on the processes by which men become more involved in caregiving, and how countries can provide incentives. Part of this research requires theoretical specification of the connections between public provisions (or their absence) and expectations, obligations, rights, and vulnerabilities in the gendered family realm. Another part involves more critical empirical assessments of theoretical mechanisms. Yet another part concerns the uncertain relationship between policies for gender equality and policies that support family care (Oliker, 2011). There is a need for careful investigations of politics and policy, interrogating the tensions between gender equality in labor market participation and gender equality in care work.

Second, there is a need for comprehensive cost/benefit analyses that cut across policy domains: increased funding in one budget area might have savings elsewhere, or, cutbacks in one budget area might lead to problems elsewhere. One of the research gaps concerns the implications of investments in home care, aimed at enabling "ageing in place", for the health and well-being of older persons and their carers. Another concerns the trade-offs between encouraging people to remain in work longer, continued reliance on families for the provision of long-term care and an expanding role for grandparents in caring for their grandchildren. These cross-cutting research topics do not allow for easy solutions-but with increasing access to national registry data, European countries offer a unique laboratory for a comprehensive assessment of policy impacts. Natural experiments, linking changes in types and levels of public provisions to intergenerational family practices, incomes, and health indicators, should become standard practice.

Acknowledgements Financial support for work on this chapter by the first author came from the European Research Council Advanced Investigator Grant (ERC, 324211) "Families in Context".

Djundeva worked on this chapter while she was a postdoctoral researcher in the Department of Public Administration and Sociology at the Erasmus University Rotterdam. Funding for her work came from the Erasmus Initiative "Vital cities and citizens". 


\section{References}

Anttonen, A., \& Häikiö, L. (2011). Care 'going market': Finnish elderly-care policies in transition. Nordic Journal of Social Research, 2. https://doi.org/10.7577/ njsr.2050.

Anttonen, A., \& Sipilä, J. (1996). European social care services: Is it possible to identify models? Journal of European Social Policy, 6(2), 87-100. https://doi.org/ 10.1177/095892879600600201.

Attias-Donfut, C., Ogg, J., \& Wolff, F. C. (2005). European patterns of intergenerational financial and time transfers. European Journal of Ageing, 2(3), 161-173. https://doi.org/10.1007/s10433-005-0008-7.

Balia, S., \& Brau, R. (2014). A country for old men? Long-term home care utilization in Europe. Health Economics, 23(10), 1185-1212. https://doi.org/10.1002/ hec. 2977.

Batson, C. D. (1998). Altruism and prosocial behavior. In D. T. Gilbert, S. T. Fiske, \& G. Lindzey (Eds.), The handbook of social psychology (Vol. 2, pp. 282-316). New York: McGraw-Hill.

Berger, L. M., \& Carlson, M. J. (2020). Family policy and complex contemporary families: A decade in review and implications for the next decade of research and policy practice. Journal of Marriage and Family, 82(1), 478-507. https://doi.org/ 10.1111/jomf.12650.

Bettio, F., \& Plantenga, J. (2004). Comparing care regimes in Europe. Feminist Economics, 10(1), 85-113. https://doi.org/10.1080/1354570042000198245.

Boldy, D., Grenade, L., Lewin, G., Karol, E., \& Burton, E. (2011). Older people’s decisions regarding 'ageing in place': A Western Australian case study. Australasian Journal on Ageing, 30(3), 136-142. https://doi.org/10.1111/j.1741-6612.2010. 00469.x.

Bom, J., Bakx, P., Schut, F., \& Van Doorslaer, E. (2019). The impact of informal caregiving for older adults on the health of various types of caregivers: A systematic review. The Gerontologist, 59(5), e629-e642. https://doi.org/10.1093/geront/ gny137.

Bonsang, E. (2007). How do middle-aged children allocate time and money transfers to their older parents in Europe? Empirica, 34(2), 171-188. https://doi.org/ 10.1007/s10663-007-9034-3.

Bouget, D., Spasova, S., \& Vanhercke, D. (2016). Work-life balance measures for persons of working age with dependent relatives in Europe: A study of national policies. European Social Policy Network. Brussels: European Commission. https:// ec.europa.eu/social/main.jsp?catId=1135\&intPageId=3588.

Brandt, M. (2013). Intergenerational help and public assistance in Europe: A case of specialization? European Societies, 15(1), 26-56. https://doi.org/10.1080/146 16696.2012.726733. 
Brandt, M., Haberkern, K., \& Szydlik, M. (2009). Intergenerational help and care in Europe. European Sociological Review, 25(5), 585-601. https://doi.org/ 10.1093/esr/jcn076.

Brody, E. M. (1981). "Women in the middle" and family help to older people. The Gerontologist, 21(5), 471-480. https://doi.org/10.1093/geront/21.5.471.

Carrera, F., Pavolini, E., Ranci, C., \& Sabbatini, A. (2013). Long-term care systems in comparative perspective: Care needs, informal and formal coverage, and social impacts in European countries. In C. Ranci \& E. Pavolini (Eds.), Reforms in long-term care policies in Europe (pp. 23-52). New York, NY: Springer.

Colombo, F., Llena-Nozal, A., Mercier, J., \& Tjadens, F. (2011). Help wanted? Providing and paying for long-term care. Paris, France: OECD Publishing. https:// doi.org/10.1787/9789264097759-en.

Costa, G. (2013). Long-term care Italian policies: A case of inertial institutional change. In C. Ranci \& E. Pavolini (Eds.), Reforms in long-term care policies in Europe (pp. 221-241). New York: Springer.

D'Addio, A. C. (2013). Pension entitlements of women with children: The role of credits within pension systems in OECD and EU countries. In R. Holzmann, E. Palmer, \& D. Robalino (Eds.), Nonfinancial defined contribution pension schemes in a changing pension world (Vol. 2): Gender, politics, and financial stability (pp. 75-110). Washington, DC: The World Bank.

Da Roit, B., Hoogenboom, M., \& Weicht, B. (2015). The gender informal care gap: A fuzzy-set analysis of cross-country variations. European Societies, 17(2), 199-218. https://doi.org/10.1080/14616696.2015.1007153.

Da Roit, B., \& Le Bihan, B. (2010). Similar and yet so different: Cash-for-care in six European countries' long-term care policies. The Milbank Quarterly, 88(3), 286-309. https://doi.org/10.1111/j.1468-0009.2010.00601.x.

Da Roit, B., \& Le Bihan, B. (2019). Cash for long-term care: Policy debates, visions, and designs on the move. Social Policy \& Administration, 53(4), 519-536. https:// doi.org/10.1111/spol.12506.

Da Roit, B., \& Weicht, B. (2013). Migrant care work and care, migration and employment regimes: A fuzzy-set analysis. Journal of European Social Policy, 23(5), 469-486. https://doi.org/10.1177/0958928713499175.

De la Maisonneuve, C., \& Oliveira Martins, J. (2013). Public spending on health and long-term care: A new set of projections (OECD Economic Policy Papers 06). https://www.oecd-ilibrary.org/docserver/5k44t7jwwr9x-en.pdf?expires $=156$ 7509851 \&id=id \&accname $=$ guest $\&$ checksum $=8730$ B66B22850FD28ACE7EC3 7DD96A39.

Dykstra, P. A. (2018). Cross-national differences in intergenerational family relations: The influence of public policy arrangements. Innovation in Aging, 2(1), 1-8. https://doi.org/10.1093/geroni/igx032.

Dykstra, P. A., \& Hagestad, G. O. (2016). How demographic patterns and social policies shape interdependence among lives in the family realm. Population Horizons, 13(2), 54-62. https://doi.org/10.1515/pophzn-2016-0004. 
Eurofound. (2016). The gender employment gap: Challenges and solutions. Luxembourg: Publications Office of the European Union. https://doi.org/10.2806/ 75749.

European Commission. (2007). Special Eurobarometer: Health and long-term care in the European Union, 283/Wave 67.3. TNS Opinion and Social. https://ec.europa. eu/commfrontoffice/publicopinion/archives/ebs/ebs_283_en.pdf.

European Commission. (2018a). The 2018 ageing report: Economic and budgetary projections for the EU Member States (2016-2070) (European Economy Institutional Paper 079). https://ec.europa.eu/info/publications/economy-finance/ 2018-ageing-report-economic-and-budgetary-projections-eu-member-states2016-2070_en.

European Commission. (2018b). The 2018 pension adequacy report: Current and future income adequacy in old age in the EU (Vol. I). Luxembourg: Publications Office of the European Union, 2018. https://op.europa.eu/en/publicationdetail/-/publication/f0e89c3f-7821-11e8-ac6a-01aa75ed71a1/language-en.

Ferrera, M. (2005). The boundaries of welfare: European integration and the new spatial politics of social protection. New York, NY: Oxford University Press.

Folbre N. (2018). The care penalty and gender inequality. In S. L. Averett, L. M. Argys, \& S. D. Hoffman (Eds.), The Oxford handbook of women and the economy (pp. 749-766). New York: Oxford University Press. https://doi.org/10.1093/oxf ordhb/9780190628963.013.2.

Fontaine, R., Gramain, A., \& Wittwer, J. (2009). Providing care for an elderly parent: Interactions among siblings? Health Economics, 18(9), 1011-1029. https://doi.org/10.1002/hec. 1533.

Foster, L., Chau, R., \& Yu, S. (2017). The impact of defamilisation measures on gender and pensions: A comparison between the UK and seven other European countries. Journal of Poverty and Social Justice, 25(3), 199-217. https://doi.org/ 10.1332/175982717X14999284090397.

Frericks, P., Jensen, P. H., \& Pfau-Effinger, B. (2014). Social rights and employment rights related to family care: Family care regimes in Europe. Journal of Aging Studies, 29, 66-77. https://doi.org/10.1016/j.jaging.2013.12.002.

Genet, N., Boerma, W. G. W., Kringos, D. S., Bouman, A., Francke, A. L., Fagerström, C., ... Devillé, W. (2011). Home care in Europe: A systematic literature review. BMC Health Services Research, 11, 207. http://www.biomedcentral.com/ $1472-6963 / 11 / 207$.

Grundy, E., \& Henretta, J. C. (2006). Between elderly parents and adult children: A new look at the intergenerational care provided by the 'sandwich generation'. Ageing \& Society 26 (5), 707-722. https://doi.org/10.1017/S0144686X060 04934.

Haberkern, K., Schmid, T., Neuberger, F., \& Grignon, M. (2012). The role of the elderly as providers and recipients of care. In OECD, The future of families to 
2030 (pp. 189-258). Paris, France: OECD Publishing. https://doi.org/10.1787/ 9789264168367-en.

Haberkern, K., Schmid, T., \& Szydlik, M. (2015). Gender differences in intergenerational care in European welfare states. Ageing \& Society, 35(2), 298-320. https:// doi.org/10.1017/S0144686X13000639.

Hagestad, G. O., \& Dykstra, P. A. (2016). Structuration of the life course: Some neglected aspects. In M. J. Shanahan, J. T. Mortimer, \& M. Kirkpatrick Johnson (Eds.), Handbook of the life course, Volume II (pp. 131-157). New York: Springer. https://doi.org/10.1007/978-3-319-20880-0_6.

Herlofson, K., \& Brandt, M. (2019, first view). Helping older parents in Europe: The importance of grandparenthood, gender and care regime. European Societies. https://doi.org/10.1080/14616696.2019.1694163.

Heymann, J., McNeill, K., \& Earle, A. (2013). Filling a critical gap: Measuring work policies that affect families globally. Community, Work \& Family, 16(3), 239-260. https://doi.org/10.1080/13668803.2013.820091.

Horner, B., \& Boldy, D. P. (2008). The benefit and burden of "ageing-in-place" in an aged care community. Australian Health Review, 32(2), 356-365. https://doi. org/10.1071/AH080356.

Igel, C., Brandt, M., Haberkern, K., \& Szydlik, M. (2009). Specialization between family and state intergenerational time transfers in Western Europe. Journal of Comparative Family Studies, 40(2), 203-226. https://doi.org/10.3138/jcfs.40. 2.203 .

Jegermalm, M., \& Grassman, E. J. (2012). Helpful citizens and caring families: Patterns of informal help and caregiving in Sweden in a 17-year perspective. International Journal of Social Welfare, 21(4), 422-432. https://doi.org/10.1111/ j.1468-2397.2011.00839.x.

Johansson, L., Sundström, G., \& Hassing, L. B. (2003). State provision down, offspring's up: The reverse substitution of old-age care in Sweden. Ageing \& Society, 23(3), 269-280. https://doi.org/10.1017/S0144686X02001071.

Kotsadam, A. (2011). Does informal eldercare impede women's employment? The case of European welfare states. Feminist Economics, 17(2), 121-144. https://doi. org/10.1080/13545701.2010.543384.

Kröger, T., \& Leinonen, A. (2012). Transformation by stealth: The retargeting of home care services in Finland. Health and Social Care in the Community, 20(3), 319-327 [Special Issue: Reforming Home Care in Ageing Societies]. https://doi. org/10.1111/j.1365-2524.2011.01047.x.

Kröger, T., \& Yeandle, S. (2013). Reconciling work and care: An international analysis. In T. Kröger \& S. Yeandle (Eds.), Combining paid work and family care: Policies and experiences in international perspective (pp. 3-21). Bristol: Policy Press. https://doi.org/10.1332/policypress/9781447306818.003.0001.

Lawton, M. P. (1982). Competence, environmental press, and the adaptation of older people. In M. P. Lawton, P. G. Windley, \& T. O. Byerts (Eds.), Aging and the environment: Theoretical approaches (pp. 33-59). New York: Springer. 
Le Bihan, B., Da Roit, B., \& Sopadzhiyan, A. (2019). The turn to optional familialism through the market: Long-term care, cash for care, and caregiving policies in Europe. Social Policy \& Administration, 53(4), 579-595. https://doi.org/10. $1111 /$ spol.12505.

Leibetseder, B., Anttonen, A., Øverbye, E., Pace, C., \& Vabo, S. I. (2017). The horizontal 're-mix' in social care: Trends and implications for service provision. In F. Martinelli, A. Anttonen, \& M. Mätzke (Eds.), Social services disrupted changes, challenges and policy implications for Europe in times of austerity (pp. 134-154). Cheltenham, UK: Elgar. https://doi.org/10.4337/9781786432117.

Leitner, S. (2003). Varieties of familialism: The caring function of the family in comparative perspective. European Societies, 5(4), 353-375. https://doi.org/10. $1080 / 1461669032000127642$.

Limmer, R., \& Schneider, N. F. (2008). Studying job-related spatial mobility in Europe. In N. F. Schneider \& G. Meil (Eds.), Mobile living across Europe I: Relevance and diversity of job-related spatial mobility in six European countries (pp. 13-45). Leverkusen, DE: Budrich.

Lohmann, H., \& Zagel, H. (2016). Family policy in comparative perspective: The concepts and measurement of familization and defamilization. Journal of European Social Policy, 26, 48-65. https://doi.org/10.1177/0958928715621712.

Lutz, H., \& Palenga-Möllenbeck, E. (2010). Care work migration in Germany: Semi-compliance and complicity. Social Policy and Society, 9(3), 419-430. https://doi.org/10.1017/S1474746410000138.

Motel-Klingebiel, A., Tesch-Roemer, C., \& Von Kondratowitz, H. J. (2005). Welfare states do not crowd out the family: Evidence for mixed responsibility from comparative analyses. Ageing \& Society, 25(6), 863-882. https://doi.org/ 10.1017/S0144686X05003971.

Murphy, M., Martikainen, P., \& Pennec, S. (2006). Demographic change and the supply of potential family supporters in Britain, Finland and France in the period 1911-2050. European Journal of Population, 22(3), 219-240. https://doi.org/10. 1007/s10680-006-9003-8.

Nadash, P., Doty, P., Mahoney, K. J., \& Von Schwanenflugel, M. (2010). European long-term care programs: Lessons for community living assistance services and supports? Health Services Research, 47(1, Part I), 309-328. https://doi.org/10. 1111/j.1475-6773.2011.01334.x.

Naldini, M., Pavolini, E., \& Solera, C. (2016). Female employment and elderly care: The role of care policies and culture in 21 European countries. Work, Employment \& Society, 30(4), 607-630. https://doi.org/10.1177/0950017015625602.

OECD. (2017). Health at a glance 2017: OECD Indicators. Paris, France: OECD Publishing. https://doi.org/10.1787/19991312.

OECD. (2019a). Health at a glance 2019: OECD indicators. https://www.oecd-ili brary.org/sites/4dd50c09-en/1/2/11/8/index.html?itemId=/content/publication/ 4dd50c09-en\&_csp_=82587932df7c06a6a3f9dab95304095d\&itemIGO= oecd\&itemContent $T$ ype $=$ book. 
OECD. (2019b). OECD health statistics 2019 definitions, sources and methods, longterm care recipients at home. Retrieved from https://stats.oecd.org/.

OECD. (2019c). OECD health statistics 2019 definitions, sources and methods, beds in residential long-term care facilities. Retrieved from https://stats.oecd.org/.

Oliker, S. (2011). Sociology and studies of gender, caregiving, and inequality. Sociology Compass, 5(11), 968-983. https://doi.org/10.1111/j.1751-9020.2011.004 17.x.

Patsios, D. (2008). The impact of the National Health Service and Community Care Act (NHSCCA) 1990 on the typologies of care of older people with functional dependencies living at home in Britain (1980-2001). Radical Statistics, 96. http://www.radstats.org.uk/no096/Patsios96.pdf.

Pavolini, E., \& Ranci, C. (2008). Restructuring the welfare state: Reforms in longterm care in Western European countries. Journal of European Social Policy, 18(3), 246-259. https://doi.org/10.1177/0958928708091058.

Pavolini, E., \& Ranci, C. (2013). Reforms in long-term care policies in Europe: An introduction. In C. Ranci \& E. Pavolini (Eds.), Reforms in long-term care policies in Europe: Investigating institutional change and social impacts (pp. 3-22). New York: Springer.

Pickard, L. (2012). Substitution between formal and informal care: A 'natural experiment' in social policy in Britain between 1985 and 2000. Ageing \& Society, 32(7), 1147-1175. https://doi.org/10.1017/S0144686X11000833.

Pinquart, M., \& Sørensen, S. (2003). Differences between caregivers and noncaregivers in psychological health and physical health: A meta-analysis. Psychology and Aging, 18(2), 250-267. https://doi.org/10.1037/0882-7974.18.2.250.

Ranci, C., \& Pavolini, E. (2013). Institutional change in long-term care: Actors, mechanisms and impacts. In C. Ranci \& E. Pavolini (Eds.), Reforms in long-term care policies in Europe (pp. 269-314). New York: Springer.

Ranci, C., \& Pavolini, E. (2015). Not all that glitters is gold: Long-term care reforms in the last two decades in Europe. Journal of European Social Policy, 25(3), 270285. https://doi.org/10.1177/0958928715588704.

Ray, R., Gornick, J. C., \& Schmitt, J. (2010). Who cares? Assessing generosity and gender equality in parental leave policy designs in 21 countries. Journal of European Social Policy, 20, 196-216. https://doi.org/10.1177/095892871036 4434.

Rechel, B., Grundy, E., Robine, J.-M., Cylus, J., Mackenbach, J. P., Knai, C., \& McKee, M. (2013). Ageing in the European Union. The Lancet, 381, 1312-1322. https://doi.org/10.1016/S0140-6736(12)62087-X.

Saraceno, C. (2010). Social inequalities in facing old-age dependency: A bigenerational perspective. Journal of European Social Policy, 20, 32-44. https:// doi.org/10.1177/0958928709352540.

Saraceno, C., \& Keck, W. (2010). Can we identify intergenerational policy regimes in Europe? European Societies, 12(5), 675-696. https://doi.org/10.1080/146 16696.2010 .483006$. 
Soldo, B. J. (1996). Cross pressures on middle-aged adults: A broader view. Journals of Gerontology: Social Sciences, 51B(6), S271-S273. https://doi.org/10.1093/ger onb/51B.6.S271.

Spasova, S., Baeten, R., Coster, S., Ghailani, D., Peña-Casas, R. \& Vanhercke, B. (2018). Challenges in long-term care in Europe: A study of national policies. European Social Policy Network (ESPN). Brussels: European Commission. Retrieved from https://ec.europa.eu/social/main.jsp?catId=738\&langId=en \&pubId=8128\& furtherPubs=yes.

Szebehely, M., \& Meagher, G. (2018). Nordic eldercare-Weak universalism becoming weaker? Journal of European Social Policy, 28(3), 294-308. https://doi. org/10.1177/0958928717735062.

Szebehely, M., \& Trydegård, G. B. (2012). Home care for older people in Sweden: A universal model in transition. Health and Social Care in the Community, 20(3), 300-309. https://doi.org/10.1111/j.1365-2524.2011.01046.x.

Taylor-Gooby, P. (Ed.). (2004). New risks, new welfare. Oxford: Oxford University Press.

Ulmanen, P., \& Szebehely, M. (2015). From the state to the family or to the market? Consequences of reduced residential eldercare in Sweden. International Journal of Social Welfare, 24(1), 81-92. https://doi.org/10.1111/ijsw.12108.

Van den Broek, T. (2013). Formalization of informal care in the Netherlands: Cost containment or gendered cost redistribution? International Journal of Feminist Approaches to Bioethics, 6(2), 185-193. https://doi.org/10.3138/ijfab.6.2.185.

Van den Broek, T., Dykstra, P. A., \& Van der Veen, R. J. (2019). Adult children stepping in? Long-term care reforms and trends in children's provision of household support to impaired parents in the Netherlands. Ageing \& Society, 39(1), 112-137. https://doi.org/10.1017/S0144686X17000836.

Van den Broek, T., \& Grundy, E. (2018, first view). Does long-term care coverage shape the impact of informal care-giving on quality of life? A difference-indifference approach. Ageing \& Society, 1-18. https://doi.org/10.1017/s0144686x 18001708.

Verbakel, E. (2014). Informal caregiving and well-being in Europe: What can ease the negative consequences for caregivers? Journal of European Social Policy, 24(5), 424-441. https://doi.org/10.1177/0958928714543902.

Vlachantoni, A. (2011). A good step forward but not far enough? The provision of care credits in European pension systems. In E. Addis, P. de Villota, F. Degavre, \& J. Eriksen (Eds.), Gender and well-being: The role of institutions (pp. 163-182). Farnham, UK: Ashgate.

Vlachantoni, A., Evandrou, M., Falkingham, F., \& Gomez-Leon, M. (2019, online first). Caught in the middle in mid-life: Provision of care across multiple generations. Ageing \& Society, 1-21. https://doi.org/10.1017/s0144686x19000047. 
Open Access This chapter is licensed under the terms of the Creative Commons Attribution 4.0 International License (http://creativecommons.org/licenses/by/4.0/), which permits use, sharing, adaptation, distribution and reproduction in any medium or format, as long as you give appropriate credit to the original author(s) and the source, provide a link to the Creative Commons licence and indicate if changes were made.

The images or other third party material in this chapter are included in the chapter's Creative Commons licence, unless indicated otherwise in a credit line to the material. If material is not included in the chapter's Creative Commons licence and your intended use is not permitted by statutory regulation or exceeds the permitted use, you will need to obtain permission directly from the copyright holder.

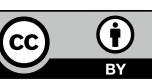

